\title{
Porous Carbonated Hydroxyapatite-Based Paraffin Wax Nanocomposite Scaffold for Bone Tissue Engineering: A Physicochemical Properties and Cell Viability Assay Analysis
}

\author{
Mona Sari ${ }^{1}$ D, Aminatun ${ }^{2}$, Tri Suciati ${ }^{3}$, Yessie Widya Sari ${ }^{4}$ and Yusril Yusuf ${ }^{1, *(D)}$ \\ 1 Department of Physics, Universitas Gadjah Mada, Yogyakarta 55281, Indonesia; monasari@mail.ugm.ac.id \\ 2 Department of Physics, Universitas Airlangga, Surabaya 60115, Indonesia; aminatun@fst.unair.ac.id \\ 3 Department of Pharmaceutics, Institut Teknologi Bandung, Bandung 40116, Indonesia; tri.suciati@fa.itb.ac.id \\ 4 Department of Physics, Institut Pertanian Bogor, Bogor 16680, Indonesia; yessie.sari@apps.ipb.ac.id \\ * Correspondence: yusril@ugm.ac.id; Tel.: +62-8122-7597-007
}

check for updates

Citation: Sari, M.; Aminatun; Suciati, T.; Sari, Y.W.; Yusuf, Y. Porous Carbonated Hydroxyapatite-Based Paraffin Wax Nanocomposite Scaffold for Bone Tissue Engineering: A Physicochemical Properties and Cell Viability Assay Analysis. Coatings 2021, 11, 1189. https://doi.org/ 10.3390/coatings11101189

Academic Editor: Grzegorz Dercz

Received: 27 July 2021

Accepted: 26 September 2021

Published: 29 September 2021

Publisher's Note: MDPI stays neutral with regard to jurisdictional claims in published maps and institutional affiliations.

Copyright: (c) 2021 by the authors. Licensee MDPI, Basel, Switzerland. This article is an open access article distributed under the terms and conditions of the Creative Commons Attribution (CC BY) license (https:/ / creativecommons.org/licenses/by/ $4.0 /)$.

\begin{abstract}
Porosity is one of the parameters of scaffold pore structure that must be developed using paraffin wax as a synthetic polymer for making porous bioceramics carbonated hydroxyapatite (CHA). This study fabricated CHA based on abalone mussel shells (Halioitis asinina); CHA/paraffin wax nanocomposite scaffolds were synthesized using paraffin wax with concentration variations of 10, 20, and $30 \mathrm{wt} . \%$. The energy-dispersive $\mathrm{X}$-ray spectroscopy (EDS) results showed that the Ca/P molar ratio of CHA was 1.72, which approaches the natural bone. The addition of paraffin wax in all concentration variation treatments caused the crystallographic properties of the $\mathrm{CHA} /$ paraffin wax nanocomposite scaffolds to decrease. The results of pore analysis suggest that the high concentration of paraffin wax in the CHA suspension is involved in the formation of more pores on the surface of the scaffold, but only CHA/paraffin wax $30 \mathrm{wt} . \%$ had a scaffold with potential to be used in media with a cellular growth orientation. The micropore analysis was also supported by the cell viability assay results for $\mathrm{CHA} /$ paraffin wax $30 \mathrm{wt}$.\% nanocomposite scaffold, where serial doses of scaffold concentrations to mouse osteoblast cells were secure. Overall, based on this analysis, the $\mathrm{CHA} /$ paraffin wax scaffold can be a candidate for bone tissue engineering.
\end{abstract}

Keywords: carbonated hydroxyapatite; paraffin wax; nanocomposite; scaffold

\section{Introduction}

Bioceramic materials, such as hydroxyapatite (HA) from the calcium phosphate family, are new alternative materials in orthopedic applications owing to their advantages over commonly used alloy materials. They can also promote bone tissue's ability to renew itself $[1,2]$. Bone consists of the mineral carbonate $(\mathrm{CO})_{3}{ }^{2-}$, which ranges from $2-8 \%$ by total weight, based on age [3,4]. The combination of HA and carbonate minerals from exterior sources and natural bone is called CHA. CHA exhibits better biological properties due to its low crystallinity and increased surface area; consequently, it shows superior bioactivity, which is usable in biomedical applications [5].

The application of $\mathrm{CHA}$ to tissue engineering has attracted significant research interest concerning the replication and reconstruction of synthetic bone for scaffold applications [4]. Bone tissue engineering has been widely developed to ameliorate bone defects by recovering and maintaining the natural function of bone tissues. One type of artificial bone tissue engineering that is widely used is bone scaffolds, which can be either polymer- or ceramic-based. [1].

Synthetic CHA can be obtained via reaction of synthetic compounds and the reaction of natural compounds. Biogenic materials as natural compounds used in the synthesis of CHA must contain calcium, such as shells and bones [4]. In this work, the CHA was produced using abalone mussel shells as the natural calcium precursor because of the high 
content of calcium carbonate $\left(\mathrm{CaCO}_{3}\right)$ in these shells, which is $90-95 \%$ [6], and can also easily be found in Indonesia [2-4]. The benefits of using calcium oxide $(\mathrm{CaO})$ derived from calcinated abalone shells, include its being locally sourced and that it can be used in green synthesis, producing only natural and nontoxic waste. A variety of techniques have been used to synthesize CHA, including co-precipitation [3,4,7,8], nano-emulsion $[9,10]$, sol-gel [11,12], mechanical alloying [13], and hydrothermal [14]. In this research, fabrication of CHA used co-precipitation as a cost-effective method [15].

Scaffold composite materials are biodegradable and biocompatible, essential for cellular growth orientation, differentiation, and proliferation $[4,16]$. The synthesis of scaffolds to promote bone growth has to consider the scaffold's porosity because this can increase the bioactivity of the scaffolds [17]. In particular, porosity increases the osteoconductivity of scaffolds. This property facilitates attachment, migration, proliferation, and phenotypic expression of bone cells for new bone formation $[1,18]$. Many procedures have been developed to fabricate bone scaffolds, consist of porogen leaching [4,17], gas foaming [19], electrospinning [20,21], sponge templating [22], and freeze-drying [23,24]. In this study, nanocomposite scaffolds were fabricated using the porogen leaching method. The benefit of this simple procedure is that it generates traces of vaporized porogen particles in the mold of pores on the scaffold. Moreover, this procedure has high synthesis efficiency and a wide variety of natural polymeric availability $[4,17]$.

Scaffold pores enable cell mobility and metabolic processes [2]. Therefore, to increase the efficacy of bone tissue engineering, several vital parameters of the scaffold's pore structure have to be carefully developed, which are pore size, geometry, orientation, uniformity, interconnectivity, and porosity $[25,26]$. Macroporous scaffolds have generally been synthesized by mixing appropriate amounts of transient polymers with powders and then evaporating, burning out, or dissolving the polymer [4,27]. Furthermore, microporous structure plays an essential role in cell growth and differentiation of scaffolds [28].

In previous studies [2,4], the porous structure of composite bioceramics using honeycomb (HCB) wax as a pore-forming agent was fabricated using the porogen leaching method. HCB wax has been synthesized from original and natural HCB from Indonesia. In this study, the pore-forming agent of the scaffold was fabricated using paraffin wax as the synthetic polymer. Paraffin wax is a potential polymer for making porous ceramics because of its good hydrophobicity and easy removal [29,30]. The quantity of wax also affects porosity. In porous ceramics, low porosity results from the lack of wax [30].

In this work, $\mathrm{CHA}$ was fabricated via co-precipitation using a precursor of $\mathrm{CaO}$ from Abalone shells. The physicochemical properties of this CHA are observed, consist with its effect on the crystallographic properties, morphology, molar ratio of $\mathrm{Ca} / \mathrm{P}$, thermal properties, and chemical compositions of CHA products. Paraffin wax porogen at concentrations of 10, 20, and $30 \mathrm{wt} . \%$ was used for the synthesis of the scaffold in order to obtain comparative data on the use of the pore agent scaffold using HCB in previous research and the potential of paraffin wax. Furthermore, the addition of paraffin wax in the nanocomposite structure in this study is expected to be a candidate pore scaffold agent for bone tissue engineering applications. Several parameters that were given a concentration variation treatment for the nanocomposite scaffold are decreased crystallite size, increased porosity and pore structure, and attachment of mouse osteoblast cells on its surface $[2,4,31,32]$. The physicochemical properties of the scaffold were analyzed using scanning electron microscopy-energy dispersive X-ray spectroscopy (SEM-EDS), $\mathrm{X}$-ray diffractometer (XRD), differential scanning calorimetry (DSC), and Fourier transform infrared spectroscopy (FTIR). The in-vitro test of the sample was characterized by cell viability assay.

\section{Materials and Methods}

The fabrication process is divided into two steps: synthesis and characterization of nano-CHA and CHA/Paraffin wax nanocomposite scaffolds by varying paraffin wax 
concentration at 10, 20, and $30 \mathrm{wt} . \%$. The schematic procedures for this work can be seen in Figure 1.

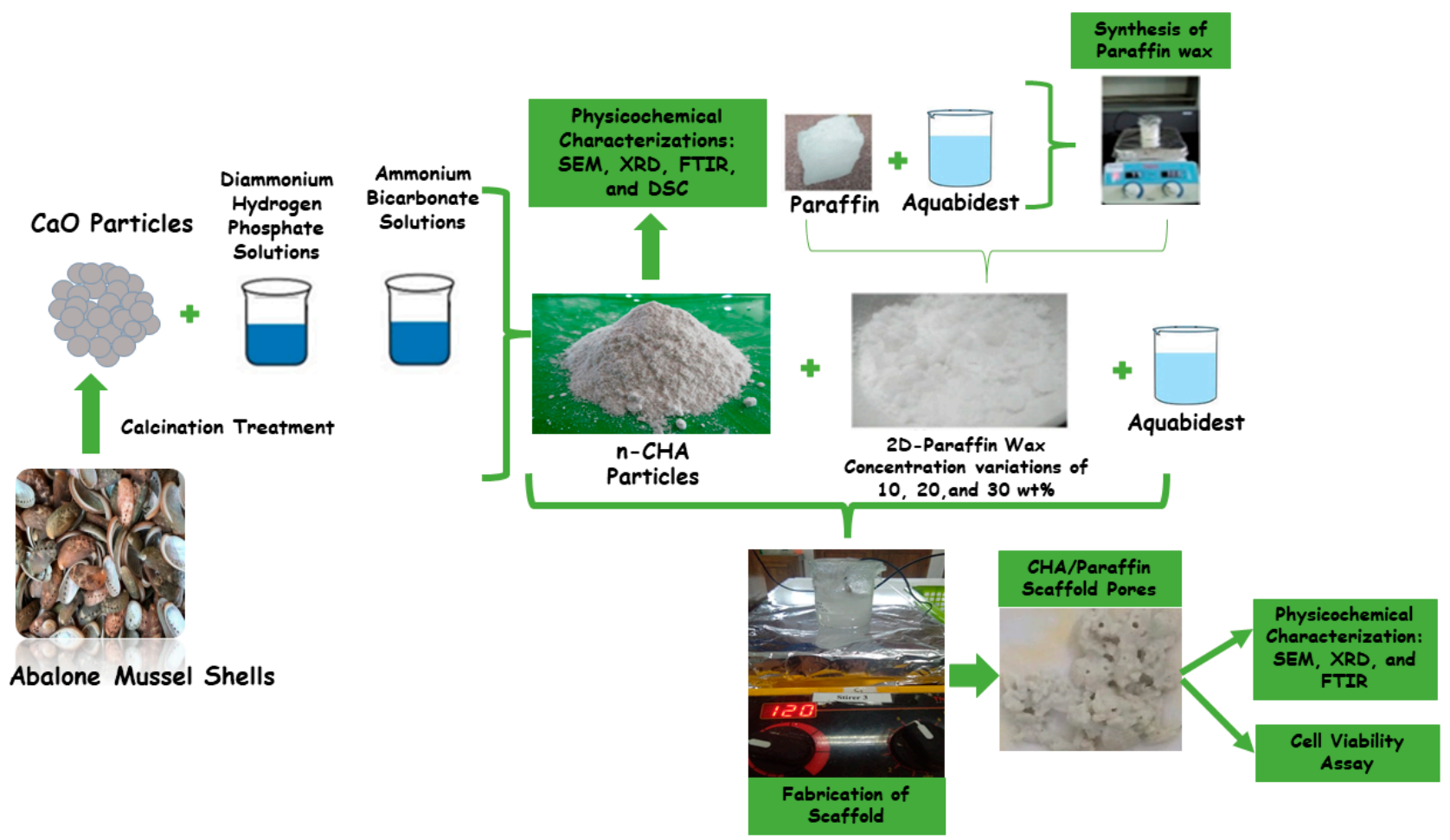

Figure 1. Schematic of methods to fabricate and characterize of $\mathrm{CHA} /$ Paraffin wax nanocomposite scaffolds with the concentration variation of 10,20 , and $30 \mathrm{wt} . \%$.

\subsection{Materials}

The materials for this study consist of the abalone mussel shells as a natural precursor of $\mathrm{CaCO}_{3}$, the precursors of diammonium hydrogen phosphate $\left((\mathrm{NH} 4)_{2} \mathrm{HPO}_{4}\right)$, ammonium bicarbonate $\left(\mathrm{NH}_{4} \mathrm{HCO}_{3}\right)$, and ammonium hydroxide $\left(\mathrm{NH}_{4} \mathrm{OH}\right) 25 \%$ solution, and the reagent for cell viability assay used the same materials as previous research $[2,4]$, except that the paraffin was purchased from Semarang, Indonesia. The percentage composition of the nanocomposite scaffold CHA/paraffin wax is shown in Table 1.

Table 1. The percentage composition of the nanocomposite scaffold CHA/paraffin wax.

\begin{tabular}{ccc}
\hline $\begin{array}{c}\text { Scaffold with Paraffin Wax } \\
\text { Concentrations Variation }\end{array}$ & CHA Mass (gr) & Paraffin Wax Mass (gr) \\
\hline CHA/paraffin wax 10 wt.\% & 0.4 & 0.044 \\
\hline CHA/paraffin wax 20 wt.\% & 0.4 & 0.100 \\
\hline CHA/paraffin wax 30 wt. \% & 0.4 & 0.171 \\
\hline
\end{tabular}

The concentration of nanocomposite scaffold was calculated by the following equation:

$$
\text { wt. \% of paraffin wax }=\frac{\text { paraffin wax mass }}{\text { paraffin wax mass }+ \text { CHA mass }}
$$

\subsection{Synthesis of Carbonated Hydroxyapatite}

$\mathrm{CaO}$ and $\mathrm{CHA}$ have been synthesized in the preliminary research $[2,4]$, so this study utilized those samples. In this study, the CHA solutions were stirred using a magnetic stirrer (Thermo Fisher Scientific, Waltham, MA, USA) at a velocity of $350 \mathrm{rpm}$ for $60 \mathrm{~min}$ 
at a temperature of $60^{\circ} \mathrm{C}$. CHA was sintered at a heat of $1050{ }^{\circ} \mathrm{C}$ for $2 \mathrm{~h}$ using a furnace (Vulcan, Yucaipa, CA, USA).

\subsection{Synthesis of CHA/Paraffin Wax Nanocomposite Scaffolds}

The fabricated CHA was mixed with a paraffin to process the sample fabrication. To obtain a porous structure, nanocomposite scaffolds were produced using CHA and paraffin wax at porogen concentrations of 10,20, and $30 \mathrm{wt} . \%$. The extraction of paraffin wax and the fabrication process of the scaffold followed the methods of previous research [4]. After sonication, the solution of paraffin wax and CHA was undertaken to an aging process for $24 \mathrm{~h}$ and then stirred at a temperature of $60^{\circ} \mathrm{C}$ at a velocity of $300 \mathrm{rpm}$ until it changed into a gel. Then, the gel was heated at a temperature of $110^{\circ} \mathrm{C}$ for $5 \mathrm{~h}$, and then calcined at $900{ }^{\circ} \mathrm{C}$ for $2 \mathrm{~h}$.

\subsection{Characterization of CHA Particles and CHA/Paraffin Wax Nanocomposite Scaffolds}

The physicochemical properties of the CHA and CHA/paraffin wax nanocomposite scaffolds were analyzed using SEM, EDS, XRD, and FTIR. The SEM (Joel JSM-6510LA-1400, Tokyo, Japan) was used to determine the morphology and particle size distribution. All $\mathrm{CHA} /$ paraffin wax samples were attached to a sample holder made of pure copper under vacuum to a pressure of $2.5 \mathrm{MPa}$ and then coated with platinum using an ion coater. The sample was entered in the SEM, and then an image pattern was generated in the form of the topography of the sample surface. The particle size distribution of CHA based on the measurements of 100 randomly selected, the pores size, and percentage of porosity of the nanocomposite scaffolds were calculated using ImageJ software version 2006 (National Institutes of Health (NIH), Bethesda, MD, USA).

EDS, incorporated in the SEM, was used to analyze the percentage of minerals elements of the CHA samples. These products were applied to analyze the molar ratio of $\mathrm{Ca} / \mathrm{P}$ in the $\mathrm{CHA}$ samples. Calculation of the $\mathrm{Ca} / \mathrm{P}$ ratio used the following equations:

$$
\text { ratio }_{\mathrm{Ca} / \mathrm{P}}=\frac{\frac{C a \text { mass }}{\text { relative atomic mass of } \mathrm{Ca}}}{\frac{P \text { mass }}{\text { relative atomic mass of } \mathrm{P}}}=0.775 \frac{\mathrm{wt} . \% \mathrm{Ca}}{\text { wt. } \% P}
$$

In this study, the analysis of the distribution of $\mathrm{Ca}$ and $\mathrm{P}$ atoms as CHA markers on the scaffold using the elemental mapping feature on EDS was not carried out.

Crystallographic properties, such as lattice parameters, crystallite size, and microstrain, functional groups, and thermal properties of $\mathrm{CHA}$ samples and $\mathrm{CHA} /$ paraffin wax nanocomposites, were specified by XRD (PAN analytical Type X'Pert Pro, Tokyo, Japan) and FTIR (Thermo Nicolet iS10, Tokyo, Japan), respectively. The XRD data were recorded in the range $2 \theta: 10^{\circ}-80^{\circ}$ using $\mathrm{Cu}-\mathrm{K} \alpha$ radiation at $\lambda=0.154 \mathrm{~nm}$ [4]. The FTIR equipment was performed in the range of $400-4000 \mathrm{~cm}^{-1}$. Measurements of the thermal properties of samples were conducted by DSC (DSC-60 Plus Shimadzu, Tokyo, Japan) and taken using a flow rate of $20 \mathrm{~mL} / \mathrm{min}$, beginning from room temperature up to $600{ }^{\circ} \mathrm{C}$ [4]. The XRD pattern, FTIR spectra, and thermal properties spectra data were analyzed using OriginPro software version 2018 (OriginLab Corporation, Northampton, MA, USA). FTIR spectra were also analyzed based on reference data using proper spectroscopy nomenclature.

The cell viability assay of the $\mathrm{CHA} /$ paraffin wax nanocomposite scaffolds, including the scaffold's extraction solution, followed the previous research [4]. In the extraction solution for the scaffolding process, CHA/paraffin wax was initially not mixed with cell culture media but with distilled water because the scaffold sample could be made into a gel even though its solubility in water was low. Then, a CHA/paraffin wax scaffold could be made serially in the cell seeding process, for which distilled water solvent would be more efficient. The scaffold extract was not added to the cell culture medium. During cell seeding, the scaffold solution was kept in the refrigerator.

Cell viability was determined using the MTT assay for an incubation periods of $24 \mathrm{~h}$ and $48 \mathrm{~h}$. Measurements were done on the CHA/paraffin wax $30 \mathrm{wt}$ \% scaffold and control 
(the well without the scaffold). The medium was discarded, and $2 \mathrm{~mL}$ of MTT solution with a concentration of $0.5 \mathrm{mg} / \mathrm{mL}$ was added to the well and incubated for $4 \mathrm{~h}$ at $37^{\circ} \mathrm{C}$ in $5 \% \mathrm{CO}_{2}$. Then, DMSO was added to the well at $100 \mu \mathrm{L} /$ well. The absorbance of MTT assay (3-(4,5-Dimethylthiazol-2-yl)-2,5-diphenyltetrazolium bromide) was recorded by Tecan Spark $^{\circledR}$ (Tecan Trading AG, Switzerland) at $570 \mathrm{~nm}[4,20,33]$. The cell viability percentage was computed by the adhering equation:

$$
\begin{aligned}
& \text { Cell Viability }(\%) \\
& =\frac{\text { absorbance of scaffold-absorbance of control media }}{\text { absorbance of control-absorbance of control media }} \times 100
\end{aligned}
$$

Then, the half maximal inhibitory concentration $\left(\mathrm{IC}_{50}\right)$ value was investigated using non-linear regression.

\subsection{Statistical Analysis}

All cell viability assay data were performed as means \pm standard deviation (SD), and one-way analysis of variance (ANOVA) was applied to elaborate the results, followed by Tukey's test ( $p$ values $<0.05$ ). These data were statistically analyzed using OriginPro software version 2018 (OriginLab Corporation, Northampton, MA, USA).

\section{Results}

\subsection{Analysis of the Physicochemical Properties of CHA}

The physicochemical properties of CHA are shown in Figure 2. Based on the morphology, shown in Figure 2a, CHA had small agglomerate lines and a solid structure. Based on Figure $2 b$, the CHA had an average particle size of $168.91 \pm 3.77 \mathrm{~nm}$ with the polydispersity at 0.02 . The EDS analysis for CHA produced a $\mathrm{Ca} / \mathrm{P}$ molar ratio of 1.72 , as shown in Figure 2c, which approaches the natural bone, i.e., 1.71.

According to the XRD analysis (Figure 2d), the pattern formed had attributes of Btype CHA and HA. The properties of HA and CHA peaks were recognized according to previous research $[2,4]$. They produced three attribute peaks at diffraction angles of $31.97^{\circ}, 33.06^{\circ}$, and $34.18^{\circ}$ with diffraction planes of (112), (300), and (202), respectively. The lattice parameters were computed to be $a=9.68 \AA$ and $c=6.85 \AA$. CHA resulted in crystallite size $(s)$, microstrain $(\varepsilon)$, and X-ray density $\left(\mathrm{d}_{\mathrm{x}}\right)$ of $15 \pm 3 \mathrm{~nm}, 0.008$, and $7.34 \mathrm{gr} / \mathrm{cm}^{3}$, respectively.

FTIR analysis was used to identify the functional groups in $\mathrm{CHA}$, namely, $\mathrm{PO}_{4}{ }^{3}$, $\mathrm{CO}_{3}{ }^{2-}$, and $\mathrm{OH}^{-}$. The FTIR test spectra exhibited that the fabricated CHA was the B-type $\mathrm{CHA}$ phase, as ensured by the appearance of $\mathrm{CO}_{3}{ }^{2-}$ stretching at $1479 \mathrm{~cm}^{-1}$ (Figure 2e). $\mathrm{PO}_{4}{ }^{3-}$ bending and stretching were observed at $603-571$ and $1092-962 \mathrm{~cm}^{-1}$, respectively. The proceeds of the FTIR spectra show $\mathrm{OH}^{-}$stretching at $3643-3572 \mathrm{~cm}^{-1}$. The absorption of $\mathrm{H}_{2} \mathrm{O}$ and $\mathrm{OH}^{-}$bending was inspected at $1633 \mathrm{~cm}^{-1}$ and $634 \mathrm{~cm}^{-1}$, respectively. The analysis of the DSC pattern can be seen in Figure 2f: CHA generated a fusion temperature of $437.61^{\circ} \mathrm{C}$ and an enthalpy of $34.53 \mathrm{j} / \mathrm{g}$.

\subsection{Analysis of the Physicochemical Properties of the CHA-Based Paraffin Wax Nanocomposite Scaffolds}

FTIR was applied to analyze the functional groups of the samples. According to the FTIR results (Figure 3), CHA with the supplemental paraffin wax at concentrations of 10, 20, and $30 \mathrm{wt} . \%$ indicated the functional groups of B-type $\mathrm{CO}_{3}$ stretching at $877-876 \mathrm{~cm}^{-1}$ and $1429-1423 \mathrm{~cm}^{-1} . \mathrm{PO}_{4}{ }^{3-}$ bending was exhibited at $603-570 \mathrm{~cm}^{-1}$ for paraffin wax concentrations of 10 and $20 \mathrm{wt} . \%$. Meanwhile, $\mathrm{PO}_{4}{ }^{3-}$ stretching was displayed at $1050-962 \mathrm{~cm}^{-1}$ for all concentration variations of paraffin wax. On the spectrum of all variations in scaffold fabrications, the $\mathrm{OH}^{-}$stretching was indicated at $3643-3570 \mathrm{~cm}^{-1}$. 


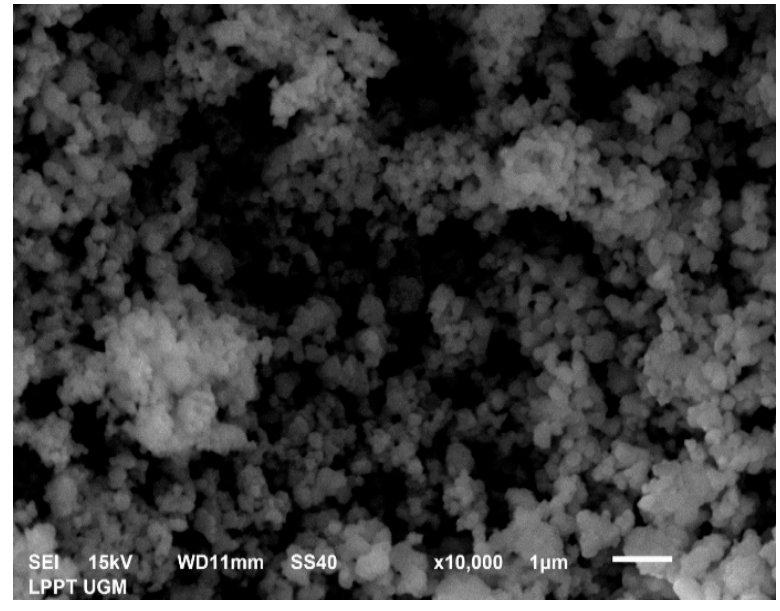

(a)

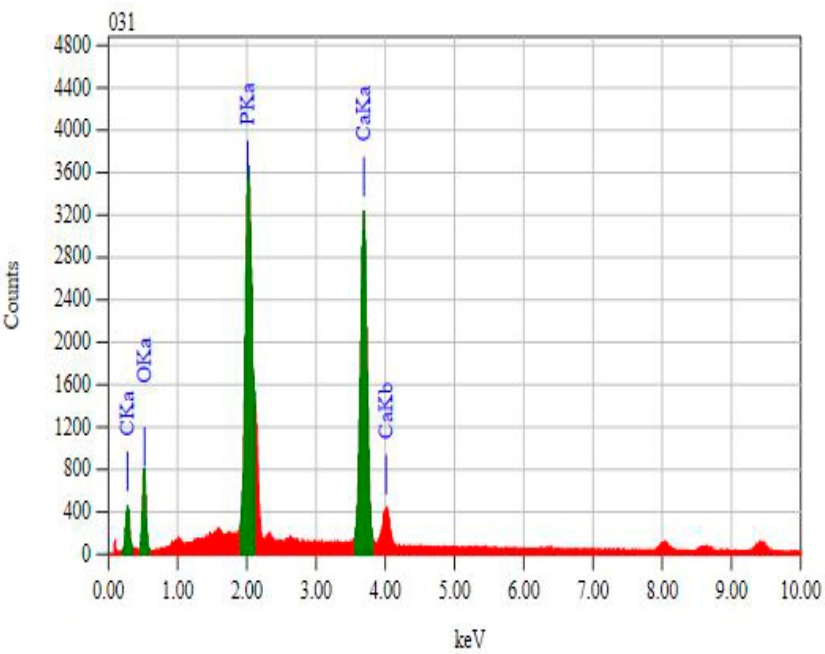

(c)

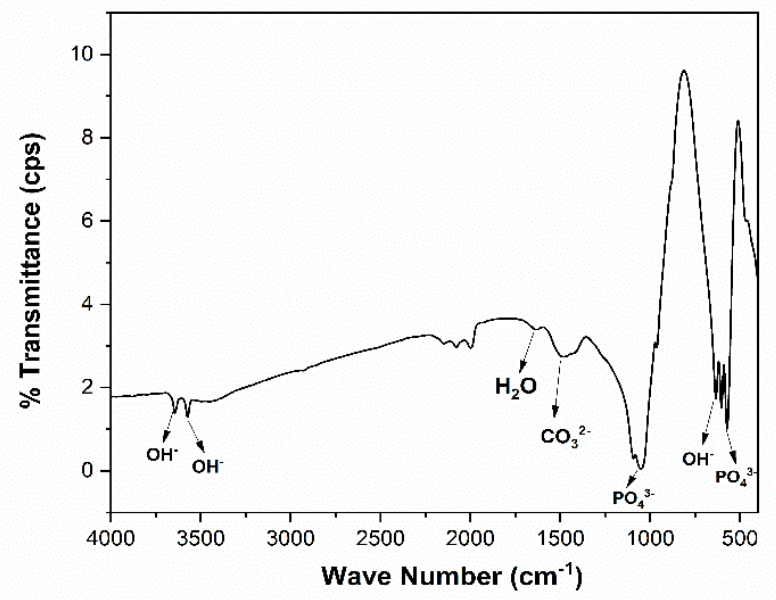

(e)

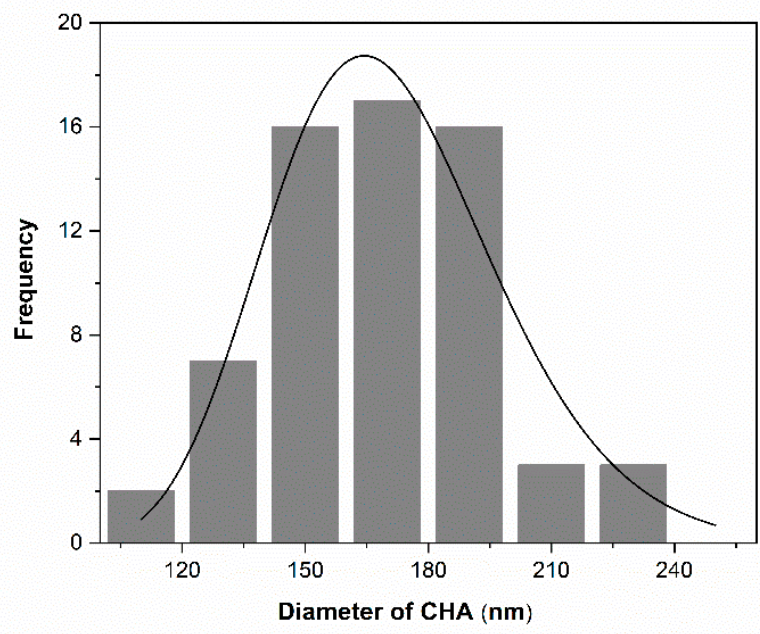

(b)

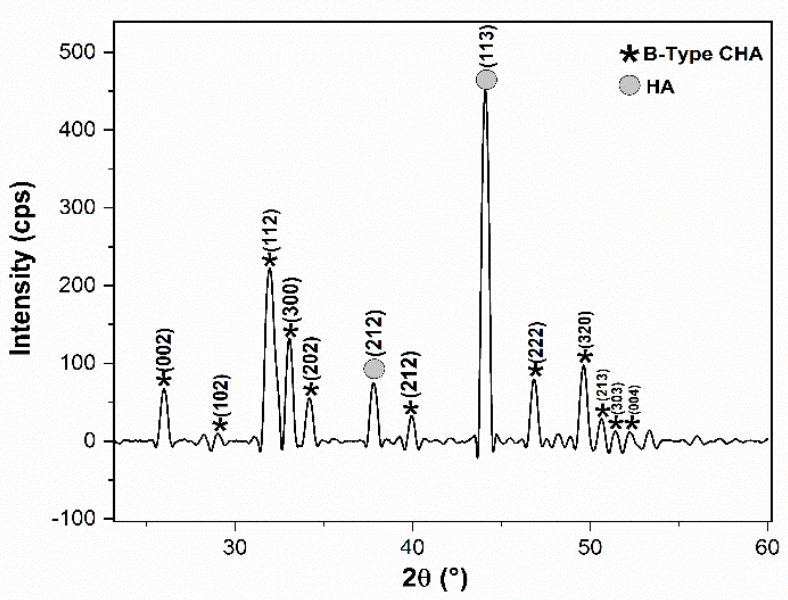

(d)

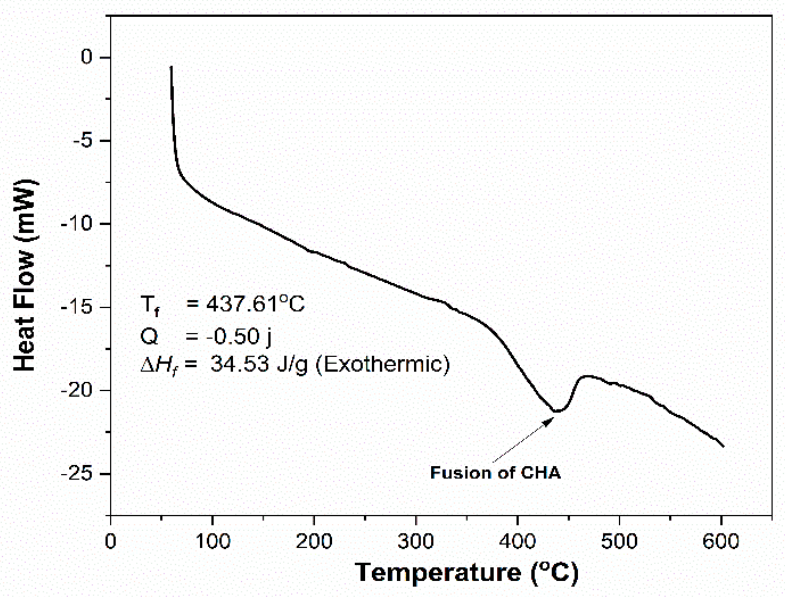

(f)

Figure 2. Physicochemical analysis of carbonated hydroxyapatite: (a) morphology; (b) particle size distribution; (c) EDS spectra; (d) XRD pattern; (e) FTIR spectra; (f) temperature fusion of CHA. 


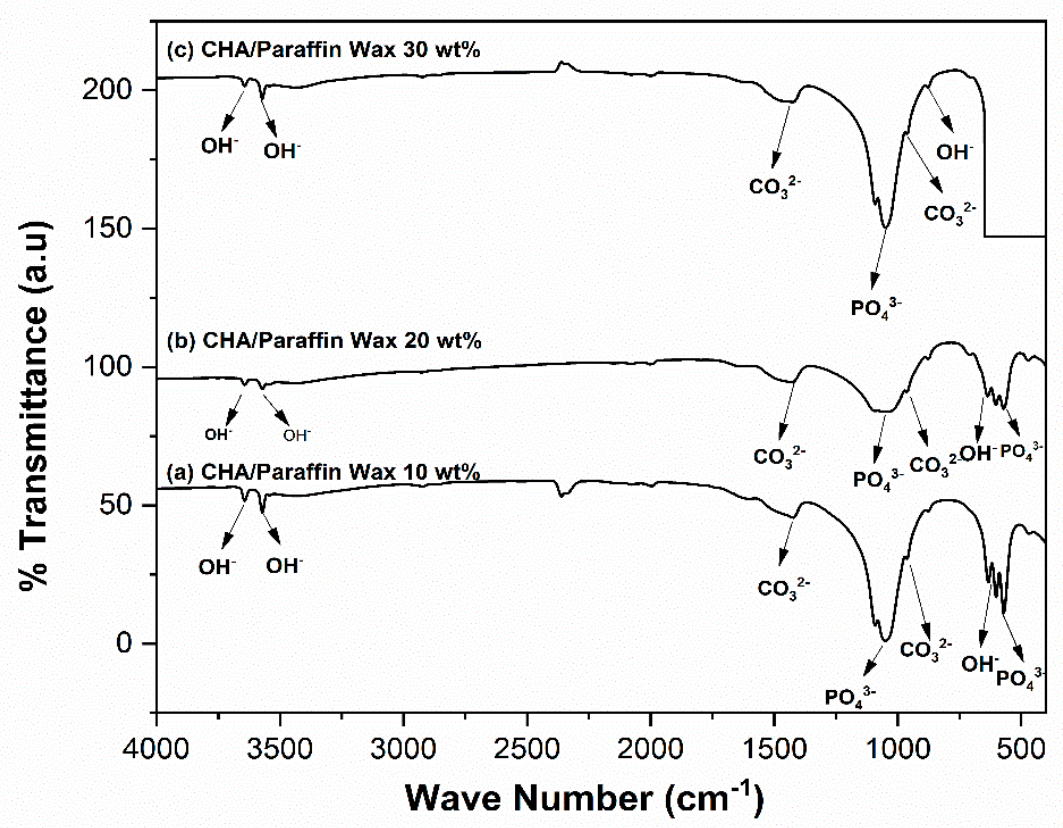

Figure 3. FTIR spectra of: (a) CHA/paraffin wax $10 \mathrm{wt}$ \%; (b) CHA/paraffin wax 20 wt.\%; (c) $\mathrm{CHA} /$ paraffin wax $30 \mathrm{wt} . \%$.

The results of the XRD pattern data for the scaffold are shown in Figure 4. As shown in Figure 4, the diffraction pattern can be recognized as the X-ray diffraction pattern of $\mathrm{CHA}$. Contrasted with the diffraction pattern of the synthesized $\mathrm{CHA}$, no other diffraction peaks emerged in any of the $\mathrm{CHA} /$ paraffin wax nanocomposite fabrications.

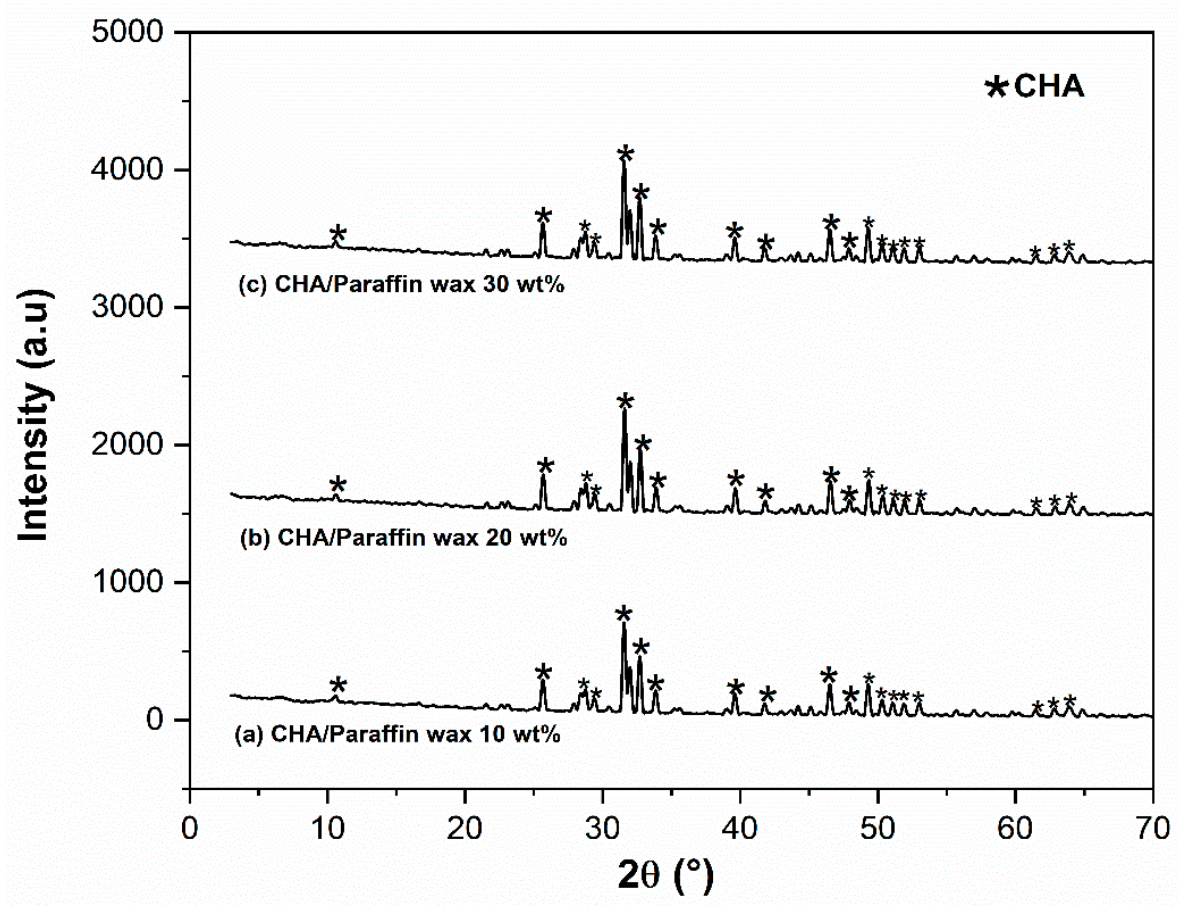

Figure 4. XRD pattern of; (a) CHA/paraffin wax 10 wt.\%; (b) CHA/paraffin wax 20 wt.\%; (c) $\mathrm{CHA} /$ paraffin wax $30 \mathrm{wt} . \%$.

The calculated crystallographic properties of scaffolds are shown in Table 2. Based on these data, the addition of paraffin wax in all concentration variation treatments generated the crystallite size to decrease. In addition, the lattice parameters of the $\mathrm{CHA} /$ paraffin 
wax nanocomposite scaffolds effected a change in the scaffold's a and c lattice parameters (Table 2). The X-ray density of the scaffold also increased because of the addition of paraffin wax in all concentration variation treatments. This indicates that the crystallinity also declined. The CHA/paraffin wax $30 \mathrm{wt} . \%$ scaffolds generated the most negligible atomic density per unit cell, having the smallest crystallinity among the samples.

Table 2. Calculation of the cystallographic properties of the CHA/paraffin wax nanocomposite scaffolds.

\begin{tabular}{|c|c|c|c|c|c|}
\hline \multirow{2}{*}{$\begin{array}{l}\text { Scaffold with Paraffin Wax } \\
\text { Concentrations Variation }\end{array}$} & \multirow{2}{*}{$\begin{array}{l}\text { Crystallite Size } \\
(\mathrm{nm})\end{array}$} & \multirow{2}{*}{$\begin{array}{l}\text { Microstrain } \\
(\varepsilon)\end{array}$} & \multicolumn{3}{|c|}{ Lattice Parameter (̊̊) } \\
\hline & & & $a$ & $c$ & $c / a$ \\
\hline CHA/paraffin wax 10 wt.\% & $15 \pm 2$ & 0.0086 & 9.79 & 6.93 & 0.707 \\
\hline CHA/paraffin wax 20 wt. $\%$ & $14 \pm 2$ & 0.0088 & 9.76 & 6.92 & 0.709 \\
\hline CHA/paraffin wax 30 wt.\% & $14 \pm 2$ & 0.0093 & 9.67 & 6.84 & 0.707 \\
\hline
\end{tabular}

According to the SEM results and Table 3, CHA 0 wt.\% did not form a pore structure (Figure 5a). The micropore structures when the pore size was below $5 \mu \mathrm{m}$ are depicted in the insets of Figure 5. According to Figure $5 b-d$, the high concentration of paraffin wax as a synthetic porogen in the CHA suspension effected the formation of more pores on the surface of the scaffold.

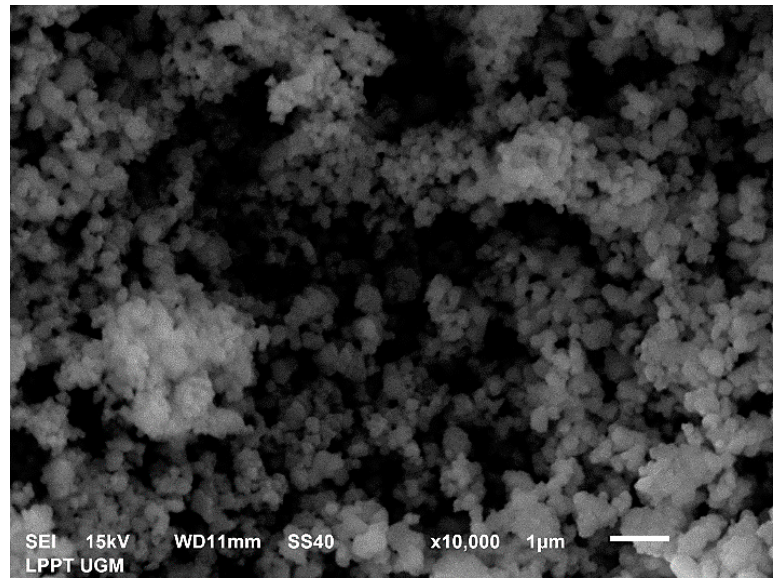

(a)

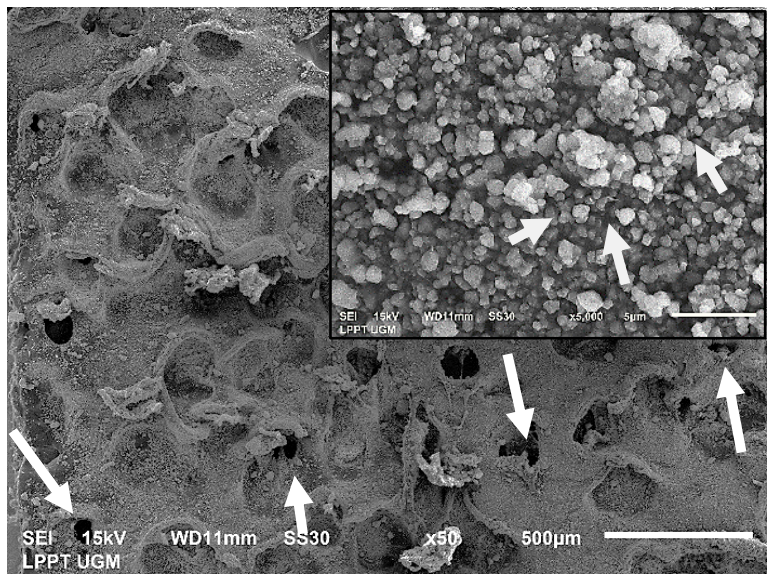

(c)

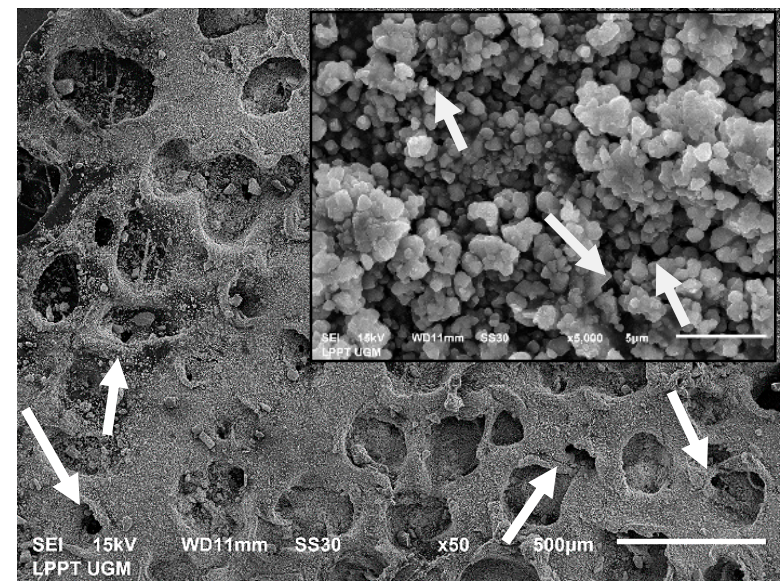

(b)

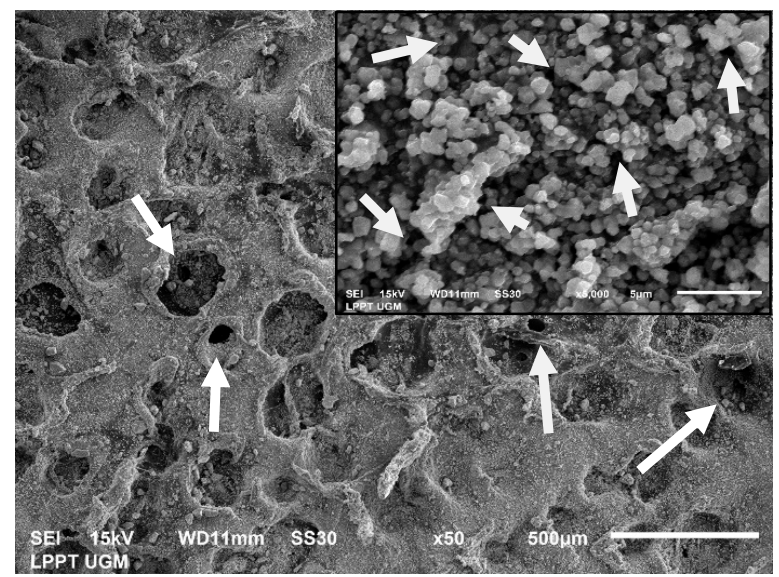

(d)

Figure 5. Morphology and porous structure of: (a) CHA/paraffin wax 0 wt.\%; (b) CHA/paraffin wax 10 wt.\%; (c) CHA/paraffin wax $20 \mathrm{wt} . \%$; (d) CHA/paraffin wax $30 \mathrm{wt} . \%$. Inset: 50× magnification (macropore) and 5000× magnification (micropore). (The white arrow indicates the macropores and micropores induced by paraffin wax). 
Table 3. The pores size of the scaffolds.

\begin{tabular}{lccc}
\hline $\begin{array}{c}\text { Scaffold with Paraffin Wax } \\
\text { Concentrations Variation }\end{array}$ & Macropore Size $(\mu \mathbf{m})$ & Micropore Size $(\mu \mathbf{m})$ & Porosity (\%) \\
\hline CHA/paraffin wax 0 wt.\% & No pore & No pore & No pore \\
\hline CHA/paraffin wax 10 wt.\% & $57 \pm 3$ & $0.5 \pm 0.03$ & 62.44 \\
\hline CHA/paraffin wax 20 wt.\% & $80 \pm 3$ & $0.6 \pm 0.02$ & 75.93 \\
\hline CHA/paraffin wax 30 wt.\% & $100 \pm 1$ & $1.0 \pm 0.02$ & 64.86 \\
\hline
\end{tabular}

The addition of paraffin wax $10 \mathrm{wt.} \%$ (Figure 6a) resulted in a uniform pore distribution, represented in green, and yielded a porosity of $62.44 \%$. The scaffold's porosity increased to $75.93 \%$ with the supplemental paraffin wax $20 \mathrm{wt} . \%$; the allocation of pores was still uniform, and the allocation of solid particles decreased (Figure 6b). By the supplemental paraffin wax $30 \mathrm{wt} . \%$, the porosity decreased to $64.86 \%$, the pore allocation was not homogeneous, and the allocation of solid particles decreased (Figure 6c).

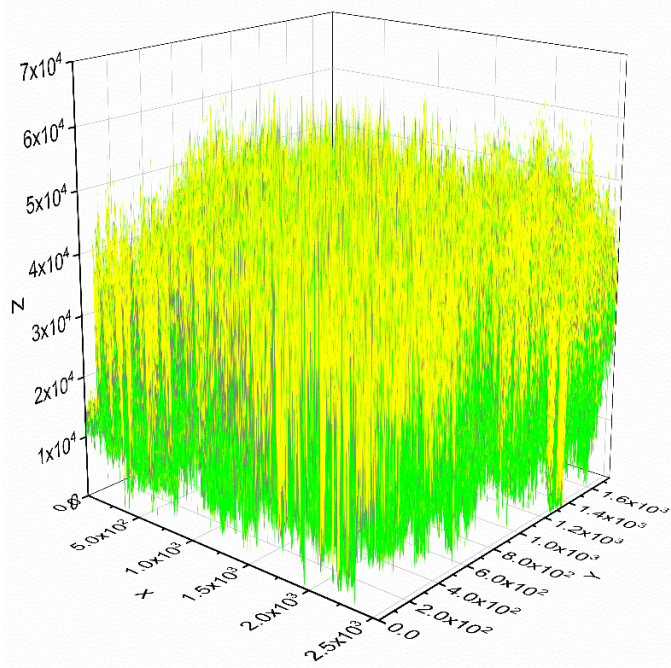

(a)

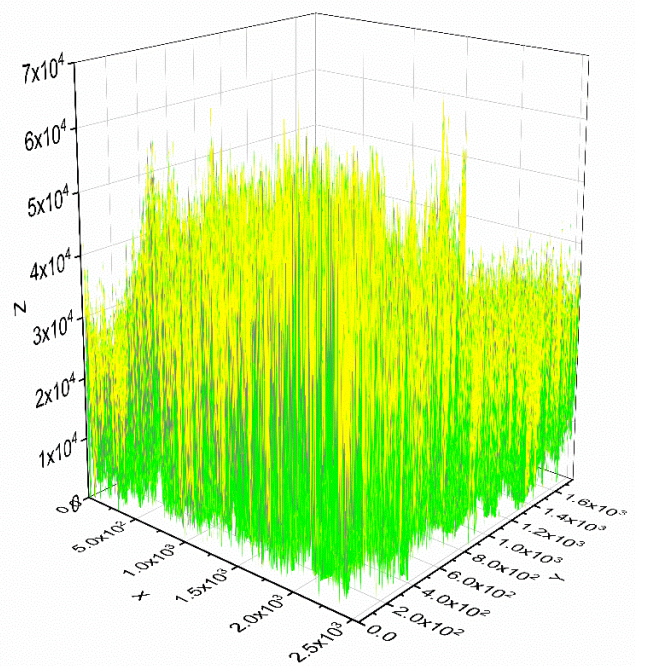

(b)

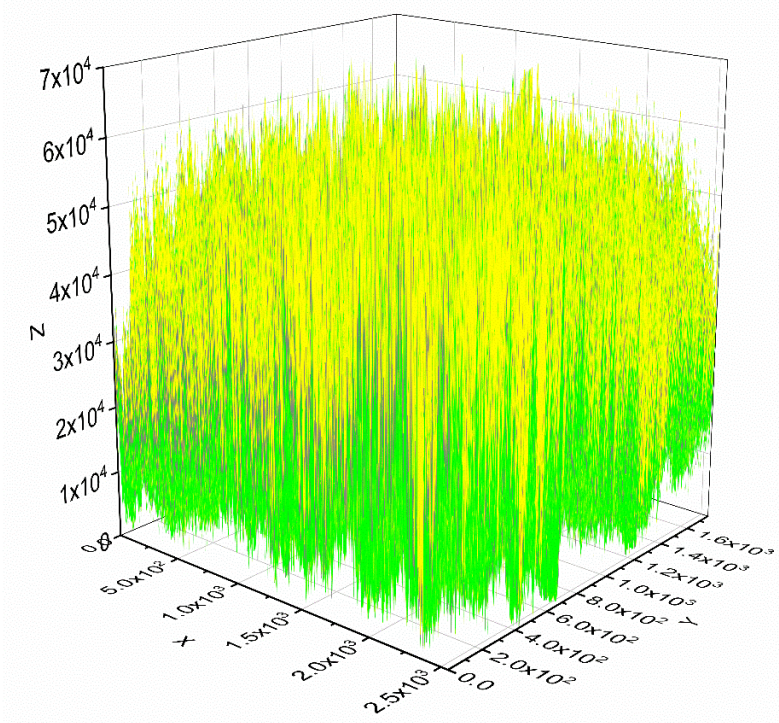

(c)

Figure 6. 3D graphics and porosity of: (a) CHA/paraffin wax 10 wt.\%; (b) CHA/paraffin wax 20 wt. \%; (c) CHA/paraffin wax $30 \mathrm{wt} . \%$. 
The morphology of MC3T3E1 cells attached to the scaffold surface is shown in Figure 7a,b. The cells were found to be well-connected to the cell network [33]. Particularly, the outcome of the cells' morphology indicated that the scaffolds' surfaces were appropriate for cells to attach. The cells attached to the scaffold surface for an incubation time of $48 \mathrm{~h}$ were mainly clustered and produced some sub-confluent structures, in contrast with samples with an incubation of $24 \mathrm{~h}$.

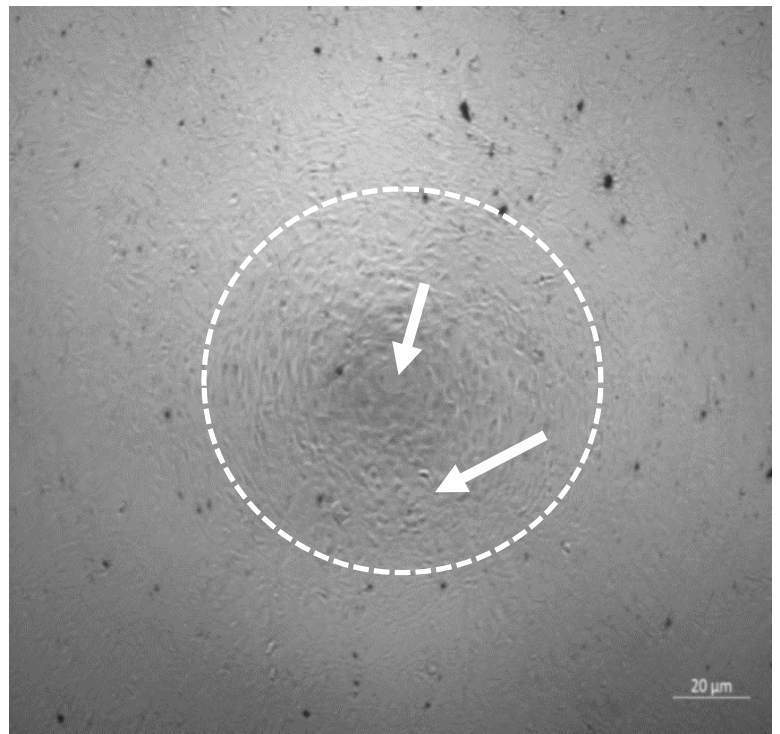

(a)

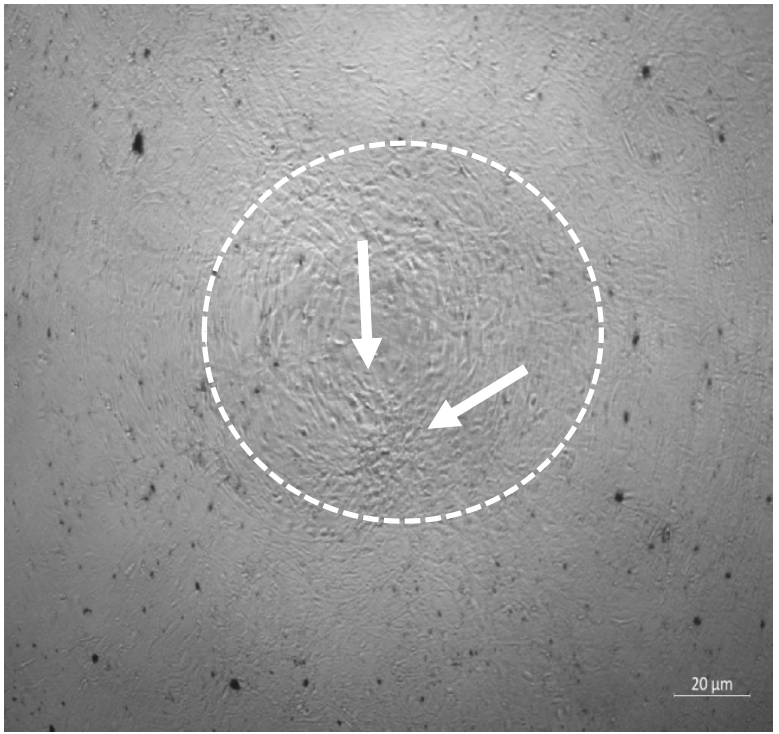

(b)

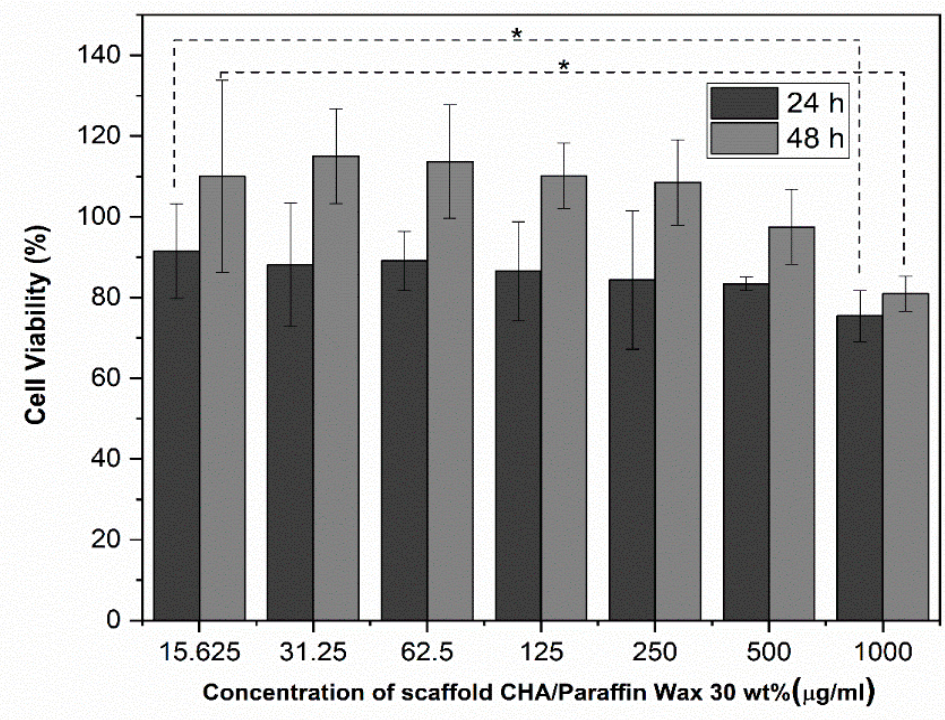

(c)

Figure 7. Morphology on CHA/paraffin wax $30 \mathrm{wt}$ \% nanocomposite scaffold after being incubated for: (a) $24 \mathrm{~h}$; (b) $48 \mathrm{~h}$ (The white arrows indicated that the MC3T3E1 cells grows in scaffold); (c) cell viability assay of the CHA/paraffin wax $30 \mathrm{wt} . \%$ nanocomposite scaffold after being incubated for $24 \mathrm{~h}$ and $48 \mathrm{~h}(*: p<0.05)$.

The results of the cell viability assay on the CHA/paraffin wax $30 \mathrm{wt} . \%$ nanocomposite scaffold show that all serial doses of scaffold concentrations to cells were secure. Based on Figure 7c and Table 4, the cell viability after incubation of 24 h showed that the $\mathrm{CHA} /$ paraffin wax $30 \mathrm{wt}$ \% nanocomposite scaffold was viable for cell attachment because 
the cell viability was $\sim 75-91 \%$. The cell viability increased to $80-115 \%$ after incubation for $48 \mathrm{~h}$. A one-way ANOVA test of the effect of incubation time on the cell viability value yielded a $p$-value of $0.002(p<0.05)$. This result showed a significant difference in the average cell viability values between the seven groups. These results were also promoted by analyzing the $\mathrm{IC}_{50}$ value of MC3T3E1 cells in the $\mathrm{CHA} /$ paraffin wax $30 \mathrm{wt}$ \% nanocomposite scaffold with incubation times of $24 \mathrm{~h}$ and $48 \mathrm{~h}$ at 1196 and $1221 \mu \mathrm{g} / \mathrm{mL}$, respectively.

Table 4. Average cell viability of the CHA/paraffin wax $30 \mathrm{wt} . \%$ nanocomposite scaffold.

\begin{tabular}{|c|c|c|c|}
\hline \multirow{3}{*}{$\begin{array}{l}\text { Concentration Serial of } \\
\text { Scaffold Solution }(\mu \mathrm{g} / \mathrm{mL})\end{array}$} & \multicolumn{2}{|c|}{ Cell Viability (\%) } & \multirow{3}{*}{$p$-Value } \\
\hline & \multicolumn{2}{|c|}{ Mean \pm SD } & \\
\hline & $24 \mathrm{~h}$ & $48 \mathrm{~h}$ & \\
\hline 15.625 & $91 \pm 12$ & $110 \pm 24$ & \multirow{7}{*}{0.002} \\
\hline 31.25 & $88 \pm 15$ & $115 \pm 12$ & \\
\hline 62.5 & $89 \pm 7$ & $114 \pm 14$ & \\
\hline 125 & $86 \pm 12$ & $110 \pm 8$ & \\
\hline 250 & $84 \pm 17$ & $108 \pm 10$ & \\
\hline 500 & $83 \pm 2$ & $98 \pm 9$ & \\
\hline 1000 & $75 \pm 6$ & $81 \pm 4$ & \\
\hline
\end{tabular}

\section{Discussion}

\subsection{Analysis of the Physicochemical Properties of $\mathrm{CHA}$}

In this research, the co-precipitation method was chosen according to specific benefits: many CHA synthesis approaches do not involve any organic solvent; the co-precipitation method is cost-effective and straightforward with a high throughput (87\%), which makes it appropriate for large-scale production, as mentioned in the introduction section [4]. It needs generous reagents and $\mathrm{Ca} / \mathrm{P}$ products with suitable phase contexture. While this method relies on $\mathrm{pH}$, stirring, and temperature, it is cheaper to carry out than the sol-gel procedure [15].

The physicochemical properties of CHA can be seen in Figure 2. The CHA particles were rounded and more regular shapes began to appear at sizes below $1 \mu \mathrm{m}$ as shown in the insets of Figure 2a. The EDS analysis for CHA indicated a $\mathrm{Ca} / \mathrm{P}$ molar ratio approaching that of natural bone, i.e., 1.71 [34], as shown in Figure 2c. This result was anticipated for CHA because the carbonate ions switched with phosphate ions in its crystal structure [4,25]. According to the XRD pattern shown in Figure $2 d$, the exchange of carbonate ions into the HA lattice structure decreased the lattice parameter $a$ [4]. In addition, the X-ray density value was appropriated to the lattice parameters of the CHA that displayed the atomic density per unit cell [15]. The FTIR test results show that the fabricated CHA was the B-type CHA (Figure 2e), which was established when carbonate ions substituted phosphate ions in the HA phase, as analyzed by EDS performed $[3,4] \cdot \mathrm{CO}_{3}{ }^{2-}$ groups in the FTIR data were due to calcium oxide's reaction with carbon dioxide in free air through fabrication [2]. DSC analysis (Figure 2f) corroborated the $\mathrm{OH}^{-}$stretching in $\mathrm{CHA}$ shown in the FTIR data.

\subsection{Analysis of the Physicochemical Properties of the CHA-Based Paraffin Wax Nanocomposite Scaffolds}

The chemical shifts through the synthesis process of scaffolds were also analyzed by FTIR [4]. The FTIR spectra of the CHA/paraffin wax nanocomposite scaffold and fabricated CHA did not show chemical decomposition in the CHA/paraffin wax nanocomposite scaffold fabrication process, as shown in Figure 3.

Interactions between the CHA particles and the paraffin wax at their interfaces can also cause the formation of an amorphous layer of paraffin wax. These interactions are affected by hydrogen bonding between the exposed $\mathrm{OH}^{-}$groups on the $\mathrm{CHA}$ particle surfaces and the polymers. This could reduce the crystallinity of the CHA/paraffin wax composite, as 
shown in Table 2 [20,35]. As shown in Figure 4, the paraffin wax was absolutely degraded from the scaffold $[4,17]$. The crystallite size was also reduced. These observations were due to because of the use of a suspension of a dry scaffold in the calcination treatment. The fluid in the compound affected the forming of dihedral angles between the particles and produced repulsive forces between the particles that prevented the CHA particle accretion $[4,17]$.

The addition of paraffin wax in all concentration variation treatments caused a lower crystallinity, which is very conducive to bone growth because low crystallinity induces dislocations, making it easier for cells to attach and differentiate [36]. The increasing microstrain identified the low crystallinity because of the addition of paraffin wax. The microstrain was a shape of crystal defect that showed as a dislocation [15]. A transformation in the microstrain on the scaffold represented that the paraffin wax used experienced the allocation of CHA particle ions in the crystal lattice spaces [4]. In addition, the $a$ and $c$ lattice parameters of the scaffold were more significant than the lattice parameters of CHA sample. Alterations in the lattice parameters happened because of the calcination during the CHA densification process. This was also shown in the shortening of the lattice in CHA [4].

An nice pore scaffold for biomedical application has a macropore size $>100 \mu \mathrm{m}$ and a micropore size $<20 \mu \mathrm{m}$ [37]. As shown in Table 3 and Figure 5, only the CHA/paraffin wax $30 \mathrm{wt} . \%$ was a potential scaffold for media-to-cell placement and cellular growth orientation because the micropore size was $\sim 1 \mu \mathrm{m}$. Commonly, when the micropore size is $1-20 \mu \mathrm{m}$, it can act as a medium for cellular growth $[4,38]$. Moreover, microporosity has a critical role in providing effective surface area for protein and ion exchange [25]. In this study, macropores with smaller sizes $(<100 \mu \mathrm{m})$ were assumed to be generated because of the gases released by the decomposition of residual paraffin wax in the scaffolds [32]. The macropore size was smaller than $100 \mu \mathrm{m}$. However, several works have revealed that the macropore size of polymeric scaffolds can be smaller than $100 \mu \mathrm{m}[2,4,39,40]$. In addition, pores smaller than $100 \mu \mathrm{m}$ promote nutrient adsorption on their surface so that the cell differentiation phase can proceed properly [41].

The particles that volatilized from the porogen in the CHA and paraffin wax mixture through the calcination process left the porous scaffold surfcace. The splitting of impurities from materials affected the frontier action of the particles [2,17]. The paraffin wax utilized in the CHA scaffold production process had the same effect as an impurity in the CHA particles [4]. The pores on the scaffold are intended to serve as points of entry of nutrients for the bone tissue $[4,17]$.

In previous studies [2,4], 3D graphics and porosity have been plotted by analyzing the scaffold's two-dimensional porosity through SEM images using the Origin software version 2018 (OriginLab Corporation, Northampton, MA, USA). The percentage of porosity can be analyzed using volume values, consist of solid volume, integral volume, and pore volume according to $3 \mathrm{D}$ graphics. The pore allocation and solid particles can be determined through the forecast of their color allocation. In this study, the pore allocation on the CHA/paraffin wax nanocomposite scaffolds is performed in green and the solid particles can be seen in yellow, as shown in Figure 6.

Porosity is an essential parameter of scaffolds because an extremely porous scaffold could offer more space for nutrient take away and cell ingrowth [37,42]. Generally, the presence of porosity in the scaffolds can play a significant role in the quality of bone formation [43]. The decrease in porosity is affected by scaffold mass gain [31]; the mass percentage of $\mathrm{CHA}$ in the nanocomposite at each concentration was the same. If the porosity of the scaffolds were $>60 \%$, the osteoblast activity would accelerate and support in the formation of new bone in the pores [37].

MTT assay has supported qualitatively significant cell viability results for nanocomposite scaffolds [44]. Cell viability is one of the preliminary tests carried out to test for possible cytotoxicity effects of scaffolds candidates in bone tissue engineering [45]. Based on the cell viability analysis as shown in Figure 7 and Table 4, the higher concentration 
of CHA in the scaffolds was associated with more frequent clusters of MC3T3E1 cells, proportional to cell viability outcomes. A higher $\mathrm{CHA}$ composition in a scaffold may lead to higher osteoconductivity in the scaffold [46].

From the analysis of porous structure, crystallographic properties, chemical composition, and cell viability tests, extracted paraffin wax as a synthetic polymer can be used as a pore-forming agent in making porous bioceramic scaffolds. This is supported by the results of micropore size on CHA/Paraffin wax $30 \mathrm{wt} . \%$. It is a potential scaffold for media-to-cell placement and cellular growth orientation. This follows the results of a previous study showing that wax extraction from HCB biopolymer can also be a scaffold pore agent, even though the HCB must reach a concentration of $40 \mathrm{wt} . \%$ to reach the ideal macropore and micropore size for bone tissue engineering applications. Therefore, extraction wax from $\mathrm{HCB}$ and paraffin wax can be used as a pore-forming agent of the scaffold.

This study has some limitations due to principal and technical challenges. Further experiments should be carried out to refine the findings of this research in the future, such as a morphological analysis at the nanoscale level and 3D porosity analysis. Smaller crystallite size causes apparent broadening of the peaks in XRD diffraction. However, the intensity of the peaks can give an idea about the crystallinity of the samples. The value of identification by high-resolution transmission electron microscopy (HRTEM) should also be studied. Mechanical properties, biocompatibility, osteoconductivity, and cell viability should also be analyzed to compare control groups and scaffolds with the addition of all paraffin wax concentrations at 10,20, and $30 \mathrm{wt} . \%$. The scaffold CHA/paraffin/wax $30 \mathrm{wt} . \%$ may also be tested for coating on titanium (Ti) alloy for bone implant applications.

\section{Conclusions}

This study provides a successful fabrication of $\mathrm{CHA}$ with a molar ratio of $\mathrm{Ca} / \mathrm{P}$ 1.72 , which approaches the $\mathrm{Ca} / \mathrm{P}$ molar ratio of natural bone. The synthesized $\mathrm{CHA}$ produced the same condition as B-type CHA, ensured by FTIR, XRD, and DSC tests. $\mathrm{CHA}$ is used for fabrication scaffolds. Fabrication of $\mathrm{CHA} /$ paraffin wax nanocomposite scaffold used paraffin wax as a pore-forming agent at concentrations of 10, 20, and $30 \mathrm{wt} . \%$. Based on the FTIR spectra results, there was no significant difference in the peaks of the samples. The addition of paraffin wax in all concentration variation treatments caused the crystallographic properties of the $\mathrm{CHA}$ /paraffin wax nanocomposite scaffolds to decrease, including crystallite size, microstrain, and lattice parameters. The results of pore analysis suggest that the high concentration of paraffin wax as a synthetic porogen in the CHA suspension produced more pores on the surface of the scaffold. Results of cell viability assay studies on the $\mathrm{CHA} /$ paraffin wax $30 \mathrm{wt} . \%$ nanocomposite scaffold confirm the non-toxicity of the material.

Author Contributions: Conceptualization, M.S., A., T.S., Y.W.S., and Y.Y.; methodology, M.S. and Y.Y.; software, M.S. and Y.Y.; validation, M.S., A., T.S., Y.W.S., and Y.Y.; formal analysis, M.S. and Y.Y.; investigation, M.S. and Y.Y.; resources, Y.Y.; data curation, M.S. and Y.Y.; writing - original draft preparation, M.S. and Y.Y.; writing-review and editing, M.S., A., T.S., Y.W.S., and Y.Y.; visualization, M.S. and Y.Y.; supervision, M.S., A., T.S., Y.W.S., and Y.Y.; project administration, M.S. and Y.Y.; funding acquisition, Y.Y. All authors have read and agreed to the published version of the manuscript.

Funding: This research was funded by Ministry of Education, Culture, Research, and Technology (2218/UN1/DITLIT/DIT-LIT/PT/2021), Directorate of Research, Universitas Gadjah Mada (796/UN1.DITLIT/DIT-LIT/PT/2021) and the Indonesian Endowment Fund for Education (LPDP) (KET-1890/LPDP.4/2019).

Institutional Review Board Statement: Not applicable.

Informed Consent Statement: Not applicable.

Data Availability Statement: The data presented in this study are available on request from the corresponding author.

Conflicts of Interest: The authors declare no conflict of interest. 


\section{References}

1. Mawuntu, V.J.; Yusuf, Y. Porous-structure engineering of hydroxyapatite-based scaffold synthesized from Pomacea canaliculata shell by using polyethylene oxide as polymeric porogen. IOP Conf. Ser. Mater. Sci. Eng. 2018, 432, 012045. [CrossRef]

2. Sari, M.; Hening, P.; Chotimah; Ana, I.D.; Yusuf, Y. Bioceramic hydroxyapatite-based scaffold with a porous strructure using honeycomb as a natural polymeric porogen for bone tissue engineering. Biomater. Res. 2021, 25, 2. [CrossRef] [PubMed]

3. Permatasari, H.A.; Supii, A.I.; Suparta, G.B.; Yusuf, Y. Characteristics of abalone mussel shells (Halioitis asinina) with calcination temperature variations as a basic material for synthesis of carbonated hydroxyapatite. Key Eng. Mater. 2019, 818, 31-36. [CrossRef]

4. Sari, M.; Hening, P.; Chotimah; Ana, I.D.; Yusuf, Y. Porous structure of bioceramics carbonated hydroxyapatite-based honeycomb scaffold for bone tissue engineering. Mater. Today Commun. 2021, 26, 102135. [CrossRef]

5. Youness, R.A.; Taha, M.A.; Ibrahim, M.A. Effect of sintering temperatures on the in vitro bioactivity, molecular structure and mechanical properties of titanium/carbonated hydroxyapatite nanobiocomposites. J. Mol. Struct. 2017, 1150, 188-195. [CrossRef]

6. Laonapakul, T. Synthesis of hydroxyapatite from biogenic wastes. KKU Eng. J. 2015, 42, 269-275.

7. Wati, R.; Yusuf, Y. Carbonated hydroxyapatite derived from Cerastoderma edule, Paphia undulata, and Meretrix meretrix shells. IOP Conf. Ser. Mater. Sci. Eng. 2019, 546, 042049. [CrossRef]

8. Anggraini, R.M.; Supii, A.I.; Suparta, G.B.; Yusuf, Y. The Effect of pH on the characteristics of carbonate hydroxyapatite based on pearl shell (Pinctada maxima). Key Eng. Mater. 2019, 818, 44-49. [CrossRef]

9. Zhou, W.Y.; Wang, M.; Cheung, W.L.; Guo, B.C.; Jia, D.M. Synthesis of carbonated hydroxyapatite nanospheres through nanoemulsion. J. Mater. Sci. Mater. Med. 2008, 19, 103-110. [CrossRef]

10. Ezekiel, I.; Kasim, S.R.; Ismail, Y.M.B.; Noor, A.F.M. Nanoemulsion synthesis of carbonated hydroxyapatite nanopowders: Effect of variant $\mathrm{CO}_{3}{ }^{2-} / \mathrm{PO}_{4}{ }^{3-}$ molar ratios on phase, morphology, and bioactivity. Ceram. Int. 2018, 44, 13082-13089. [CrossRef]

11. Rajabi-Zamani, A.H.; Behnamghader, A.; Kazemzadeh, A. Synthesis of nanocrystalline carbonated hydroxyapatite powder via nonalkoxide sol-gel method. Mater. Sci. Eng. C 2008, 28, 1326-1329. [CrossRef]

12. Fathi, M.H.; Hanifi, A.; Mortazavi, V. Preparation and bioactivity evaluation of bone-like hydroxyapatite nanopow. J. Mater. Process. Technol. 2007, 202, 536-542. [CrossRef]

13. Lala, S.; Brahmachari, S.; Das, P.K.; Das, D.; Kar, T.; Pradhan, S.K. Biocompatible nanocrystalline natural bonelike carbonated hydroxyapatite synthesized by mechanical alloying in a record minimum time. Mater. Sci. Eng. C 2014, 42, 647-656. [CrossRef] [PubMed]

14. Kong, W.; Zhao, K.; Gao, C.; Zhu, P. Synthesis and characterization of carbonated hydroxyapatite with layered structure. Mater. Lett. 2019, 255, 126552. [CrossRef]

15. Sari, M.; Yusuf, Y. Synthesis and characterization of hydroxyapatite based on green mussel shells (Perna viridis) with calcination temperature variation using the precipitation method. Int. J. Nanoelectron. Mater. 2018, 11, 357-370.

16. Chen, P.; Liu, L.; Pan, J.; Mei, J.; Li, C.; Zheng, Y. Biomimetic composite scaffold of hydroxyapatite/gelatin-chitosan core-shell nanofibers for bone tissue engineering. Mater. Sci. Eng. C 2019, 9, 325-335. [CrossRef] [PubMed]

17. Mawuntu, V.J.; Yusuf, Y. Porous structure engineering of bioceramic hydroxyapatite-based scaffolds using PVA, PVP, and PEO as polymeric porogens. J. Asian Ceram. Soc. 2019, 7, 161-169. [CrossRef]

18. Legeros, R.Z.; Kijkowska, R.; Bautista, C.; Legeros, J.P. Synergistic effects of magnesium and carbonate on properties of biological and synthetic apatites. Connect. Tissue Res. 1995, 33, 203-209. [CrossRef]

19. Manavitehrani, I.; Le, T.Y.L.; Daly, S.; Wang, Y.; Maitz, P.K.; Schindeler, A.; Dehghani, F. Formation of porous biodegradable scaffolds based on poly (propylene carbonate) using gas foaming technology. Mater. Sci. Eng. C 2019, 96, 824-830. [CrossRef]

20. Januariyasa, I.K.; Ana, I.D.; Yusuf, Y. Nanofibrous poly (vinyl alcohol)/chitosan contained carbonated hydroxyapatite nanoparticles scaffold for bone tissue engineering. Mater. Sci. Eng. C 2020, 107, 110347. [CrossRef]

21. Ranganathan, S.; Balagangadharan, K.; Selvamurugan, N. Chitosan and gelatin-based electrospun fibers for bone tissue engineering. Int. J. Biol. Macromol. 2019, 133, 354-364. [CrossRef] [PubMed]

22. Jo, I.; Shin, K.; Soon, Y.; Koh, Y.; Lee, J.; Kim, H. Highly porous hydroxyapatite scaffolds with elongated pores using stretched polymeric sponges as novel template. Mater. Lett. 2009, 63, 1702-1704. [CrossRef]

23. Soltani, M.; Yousefpour, M.; Taherin, Z. Porous fluorhydroxyapatite-magnesium-gelatin novel composite scaffold based on freeze-drying mechanism for bone tissue engineering application. Mater. Lett. 2019, 244, 195-198. [CrossRef]

24. Govindan, R.; Gu, F.L.; Karthi, S.; Girija, E.K. Effect of phosphate glass reinforcement on the mechanical and biological properties of freeze-dried gelatin composite scaffolds for bone tissue engineering applications. Mater. Today Commun. 2020, $22,100765$. [CrossRef]

25. Januariyasa, I.K.; Yusuf, Y. Porous carbonated hydroxyapatite-based scaffold using simple gas foaming method. J. Asian Ceram. Soc. 2020, 8, 634-641. [CrossRef]

26. Hayashi, K.; Munar, M.L.; Ishikawa, K. Effects of macropore size in carbonate apatite honeycomb scaffolds on bone regeneration. Mater. Sci. Eng. C 2020, 111, 110848. [CrossRef]

27. Hayashi, K.; Kishida, R.; Tsuchiya, A.; Ishikawa, K. Honeycomb blocks composed of carbonate apatite, $\beta$-tricalcium phosphate, and hydroxyapatite for bone regeneration: Effects of composition on biological responses. Mater. Today Bio $2019,4,100031$. [CrossRef]

28. Ishikawa, K.; Munar, M.L.; Tsuru, K.; Miyamoto, Y. Fabrication of carbonate apatite honeycomb and its tissue response. J. Biomed. Mater. Res. Part A 2019, 107, 1014-1020. [CrossRef] 
29. Shao, Y.; Yang, F.; Qin, Q.; Zhou, Y.; Chen, C.; Liu, P.; He, X.; Guo, Z. Shaping and mechanical performance of gelcasting Ti6Al4V alloys with paraffin wax and stearic acid coated on powder surface. Mater. Today Commun. 2020, 25, 101533. [CrossRef]

30. Li, R.; Zhou, Y.; Duan, X. A novel composite phase change material with paraffin wax in tailings porous ceramics. Appl. Therm. Eng. 2019, 151, 115-123. [CrossRef]

31. Zhao, J.; Duan, K.; Zhang, J.W.; Lu, X.; Weng, J. The influence of polymer concentrations on the structure and mechanical properties of porous polycaprolactone-coated hydroxyapatite scaffolds. Appl. Surf. Sci. 2010, 256, 4586-4590. [CrossRef]

32. Ruiz-Aguilar, C.; Olivares-pinto, U.; Drew, R.A.L.; Aguilar-Reyes, E.A.; Alfonso, I. Porogen effect on structural and physical properties of $\beta$-TCP scaffolds for bone tissue regeneration. IRBM 2020, 42, 302-312. [CrossRef]

33. Zhu, J.; Kong, Q.; Zheng, S.; Wang, Y.; Jiao, Z.; Nie, Y.; Liu, T.; Song, K. Toxicological evaluation of ionic liquid in a biological functional tissue construct model based on nano-hydroxyapatite/chitosan/gelatin hybrid scaffolds. Int. J. Biol. Macromol. 2020, 158, 800-810. [CrossRef]

34. Desai, A.Y. Fabrication and Characterization of Titanium-Doped Hydroxyapatite Thin Films. Master's Thesis, University of Cambridge, Cambridge, UK, 2007.

35. Nejati, E.; Mirzadeh, H.; Zandi, M. Synthesis and characterization of nano-hydroxyapatite rods/poly (L-lactide acid) composite scaffolds for bone tissue engineering. Compos. Part A Appl. Sci. Manuf. 2008, 39, 1589-1596. [CrossRef]

36. Ana, I.D. Bone Substituting Materials in Dental Implantology; Springer: Cham, Switzerland, 2019; pp. 121-141.

37. Bose, S.; Roy, M.; Bandyopadhyay, A. Recent advances in bone tissue engineering scaffolds. Trends Biotechnol. 2012, 30, 546-554. [CrossRef] [PubMed]

38. Sánchez-Salcedo, S.; Arcos, D.; Vallet-Regi, M. Upgrading calcium phosphate scaffolds for tissue engineering applications. Key Eng. Mater. 2008, 377, 19-42. [CrossRef]

39. Reinwald, Y.; Johal, R.K.; Ghaemmaghami, A.M.; Rose, F.R.A.J.; Howdle, S.M.; Shakesheff, K.M. Interconnectivity and permeability of supercritical fluid-foamed scaffolds and the effect of their structural properties on cell distribution. Polymer 2014, 55, 435-444. [CrossRef]

40. Mehr, N.G.; Li, X.; Ariganello, M.B.; Hoemann, C.D.; Favis, B.D. Poly( $\varepsilon$-caprolactone) scaffolds of highly controlled porosity and interconnectivity derived from co-continuous polymer blends: Model bead and cell infiltration behavior. J. Mater. Sci. Mater. Med. 2014, 25, 2083-2093. [CrossRef] [PubMed]

41. Christy, P.N.; Basha, S.K.; Kumari, V.S.; Bashir, A.K.H.; Maaza, M.; Kaviyarasu, K.; Arasu, M.V.; Al-Dhabi, N.A.; Ignacimuthu, S. Biopolymeric nanocomposite scaffolds for bone tissue engineering applications-A review. J. Drug Deliv. Sci. Technol. 2020, 55, 101452. [CrossRef]

42. Lou, T.; Wang, X.; Song, G.; Gu, Z.; Yang, Z. Structure and properties of PLLA/ $\beta$-TCP nanocomposite scaffolds for bone tissue engineering. J. Mater. Sci. Mater. Med. 2015, 26, 5366. [CrossRef]

43. Scaglione, S.; Giannoni, P.; Bianchini, P.; Sandri, M.; Marotta, R.; Firpo, G.; Valbusa, U.; Tampieri, A.; Diaspora, A.; Bianco, P.; et al. Order versus Disorder: In vivo bone formation within osteoconductive scaffolds. Sci. Rep. 2011, 2, 274. [CrossRef]

44. Kanimozhi, K.; Basha, S.K.; Kumari, V.S.; Kaviyarasu, K.; Maaza, M. In vitro cytocompatibility of chitosan/PVA/methylcellulosenanocellulose nanocomposite scaffolds using L929 fibroblast cells. Appl. Surf. Sci. 2018, 449, 574-583. [CrossRef]

45. Stocco, T.D.; Antonioli, E.; Elias, C.D.M.V.; Rodrigues, B.V.M.; Siqueira, I.A.W.D.B.; Ferretti, M.; Marciano, F.R.; Lobo, A.O. Cell viability of porous Poly (D,L-lactic acid)/vertically aligned carbon nanotubes/nanohydroxyapatite scaffolds for osteochondral tissue engineering. Materials 2019, 12, 849. [CrossRef] [PubMed]

46. Heydari, Z.; Mohebbi-kalhori, D.; Afarani, M.S. Engineered electrospun polycaprolactone (PCL)/octacalcium phosphate (OCP) scaffold for bone tissue engineering. Mater. Sci. Eng. C 2017, 81, 127-132. [CrossRef] [PubMed] 